\title{
Assessment of 5-HT 7 Receptor Agonists Selectivity Using Nociceptive and Thermoregulation Tests in Knockout versus Wild-Type Mice
}

\author{
Alex Brenchat, ${ }^{1}$ Maria Rocasalbas, ${ }^{1}$ Daniel Zamanillo, ${ }^{1}$ Michel Hamon, ${ }^{2}$ \\ José Miguel Vela, ${ }^{1}$ and Luz Romero ${ }^{1}$ \\ ${ }^{1}$ Department of Pharmacology, Drug Discovery and Preclinical Development, ESTEVE, Avenida Mare de Déu de Montserrat 221, \\ 08041 Barcelona, Spain \\ ${ }^{2}$ UMR 894 INSERM-CPN/UPMC, Faculté de Médecine Pierre et Marie Curie, Site Pitié-Salpêtrière, 91 boulevard de l'Hôpital, \\ 75634 Paris Cedex 13, France
}

Correspondence should be addressed to Luz Romero, lromero@esteve.es

Received 17 February 2012; Accepted 27 April 2012

Academic Editor: Karim A. Alkadhi

Copyright ( 2012 Alex Brenchat et al. This is an open access article distributed under the Creative Commons Attribution License, which permits unrestricted use, distribution, and reproduction in any medium, provided the original work is properly cited.

\begin{abstract}
No study has ever examined the effect of $5-\mathrm{HT}_{7}$ receptor agonists on nociception by using 5 - $\mathrm{HT}_{7}$ receptor knockout mice. Basal sensitivity to noxious heat stimuli and formalin-induced nociception in both phase I and II of the formalin test did not differ in 5$\mathrm{HT}_{7}$ receptor knockout mice and paired wild-type controls. Similarly, there was no significant difference in basal body temperature between both genotypes. Subcutaneous administration of 5-HT 7 receptor agonists AS-19 (10 mg/kg), E-57431 (10 mg/kg), and E$55888(20 \mathrm{mg} / \mathrm{kg})$ significantly reduced formalin-induced licking/biting behavior during the phase II of the test in wild-type but not in $5-\mathrm{HT}_{7}$ receptor knockout mice. At these active analgesic doses, none of the three $5-\mathrm{HT}_{7}$ receptor agonists modified the basal body temperature neither in wild-type nor in $5-\mathrm{HT}_{7}$ receptor knockout mice. However, a significant decrease in body temperature was observed at a higher dose $(20 \mathrm{mg} / \mathrm{kg})$ of AS-19 and E-57431 in both genotypes. Our data strongly suggest that the 5- $\mathrm{HT}_{7}$ receptor agonists AS-19, E-57431, and E-55888 produce antinociception in the formalin test by activating 5 - $\mathrm{HT}_{7}$ receptors. These results also strengthen the idea that the $5-\mathrm{HT}_{7}$ receptor plays a role in thermoregulation, but by acting in concert with other receptors.
\end{abstract}

\section{Introduction}

The $5-\mathrm{HT}_{7}$ receptor has been cloned from different genomes and its binding profile is consistent across species and between cloned and native receptors [1,2]. In recent years, considerable efforts have focused on the development of selective $5-\mathrm{HT}_{7}$ receptor agonists and antagonists. To date, the search for $5-\mathrm{HT}_{7}$ receptor antagonists has led to the discovery of LY215840 [3], SB-258719 [4], DR4004 [5], SB269970 [6], and SB-656104-A [7]. Regarding 5- $\mathrm{HT}_{7}$ receptor agonists, AS-19 [8, 9], MSD-5a [10], LP-44 [11], LP-211 [12], E-55888 [13], and E-57431 [14] have been developed. However, most of these agonists display rather modest selectivity because their affinity for the $5-\mathrm{HT}_{7}$ type is only $11-$ fold higher than for 5- $\mathrm{HT}_{1 \mathrm{D}}$ in case of AS-19 [13], 28.6-fold higher than for $5-\mathrm{HT}_{1 \mathrm{~A}}$ in case of MSD-5a [10], and 33-fold higher than for dopamine D2 receptor [15], and 5-14-fold higher than for $5-\mathrm{HT}_{1 \mathrm{~B}}, 5-\mathrm{HT}_{2 \mathrm{~B}}, 5-\mathrm{HT}_{2 \mathrm{C}}$, and $5-\mathrm{HT}_{5 \mathrm{~A}}$ in case of LP-211 [16]. Indeed, among 5-HT 7 receptor agonists, only E-55888 and E-57431 seem to have a satisfactory selectivity with affinity for the $5-\mathrm{HT}_{7}$ receptor 280 -fold higher than for $5-\mathrm{HT}_{1 \mathrm{~A}}$ and 112.7 -fold higher than for $5-\mathrm{HT}_{1 \mathrm{D}}$, respectively [13] (see Table 1). When tested in a functional assay, 5$\mathrm{HT}_{7}$ receptor agonists concentration dependently increased cAMP formation in HEK-293F/h5-HT 7 cells. AS- 19 has been found to behave as a potent $\left(\mathrm{EC}_{50}=9 \pm 1 \mathrm{nM}\right)$ but partial 5$\mathrm{HT}_{7}$ receptor agonist, with a maximal effect reaching $77 \%$ of that of 5-HT [13]. However, E-55888 and E-57431 behave as full agonists, with efficacies $\left(E_{\max }=99 \pm 1 \%\right.$ and $94.5 \pm$ $1 \%$, resp. $)$ and potencies $\left(\mathrm{EC}_{50}=16 \pm 1 \mathrm{nM}\right.$ and $21.5 \pm$ $1 \mathrm{nM}$ ) similar to those of $5-\mathrm{HT}$, as previously described $[13,14]$. 
TABLE 1: Binding profiles of the 5- $\mathrm{HT}_{7}$ receptor agonists AS-19, E-57431, and E-55888.

\begin{tabular}{|c|c|c|c|}
\hline \multirow{2}{*}{ Receptor } & \multicolumn{3}{|c|}{ Affinity $\left(\mathrm{K}_{i}(\mathrm{nM})\right)$} \\
\hline & AS-19 & E-57431 & E-55888 \\
\hline h5- $\mathrm{HT}_{1 \mathrm{~A}}$ & $89.7(149.5 \mathrm{x})$ & n.s. & $700(280 x)$ \\
\hline $\mathrm{r} 5-\mathrm{HT}_{1 \mathrm{~B}}$ & $490(816.6 \mathrm{x})$ & n.s. & n.s. \\
\hline h5-HT $1 \mathrm{D}$ & $6.6(11 \mathrm{x})$ & $53(112.7 x)$ & n.s. \\
\hline h5- $\mathrm{HT}_{2 \mathrm{~A}}$ & n.s. & $560(1191.5 \mathrm{x})$ & n.s. \\
\hline h5- $\mathrm{HT}_{2 \mathrm{~B}}$ & n.s. & n.s. & n.s. \\
\hline h5- $\mathrm{HT}_{2 \mathrm{C}}$ & n.s. & n.s. & n.s. \\
\hline h5- $\mathrm{HT}_{3}$ & n.s. & n.s. & n.s. \\
\hline h5- $\mathrm{HT}_{4 \mathrm{e}}$ & - & n.s. & n.s. \\
\hline gp5- $\mathrm{HT}_{4}$ & n.s. & n.s. & - \\
\hline $\mathrm{h} 5-\mathrm{HT}_{5 \mathrm{~A}}$ & $98.5(164.2 \mathrm{x})$ & n.s. & n.s. \\
\hline h5- $\mathrm{HT}_{6}$ & n.s. & n.s. & n.s. \\
\hline $\mathrm{h} 5-\mathrm{HT}_{7}$ & 0.6 & 0.47 & 2.5 \\
\hline h5-HT transporter (SERT) & n.s. & n.s. & n.s. \\
\hline Other receptors & n.s. ${ }^{a}$ & n.s. ${ }^{b}$ & n.s. ${ }^{\mathrm{a}}$ \\
\hline
\end{tabular}

n.s.: not significant $\left(\mathrm{K}_{i}>1 \mu \mathrm{M}\right.$ or less than $50 \%$ inhibition of specific radioligand binding at $\left.1 \mu \mathrm{M}\right)$;

—: data not available.

gp: guinea pig; h: human; r: rat.

Data obtained from Brenchat et al. [13, 14]

Data in parentheses after $\mathrm{K}_{i}$ values represent the affinity ratio versus $5-\mathrm{HT}_{7}$ receptors calculated as $\mathrm{K}_{i}$ for the tested receptor/ $\mathrm{K}_{i}$ for 5 - $\mathrm{HT}_{7}$ receptor. It is expressed as number-fold higher $(\mathrm{x})$ for $5-\mathrm{HT}_{7}$ than for the tested receptor.

a

${ }^{\mathrm{b}}$ See the panel of other receptors assayed [14].

From data obtained with these pharmacological tools, it has been claimed that $5-\mathrm{HT}_{7}$ receptors are involved in a number of physiological and pathophysiological phenomena such as nociception and thermoregulation. Data supporting a role for $5-\mathrm{HT}_{7}$ receptors in pain control mostly suggest an antinociceptive effect of $5-\mathrm{HT}_{7}$ receptor activation in the CNS and, in contrast, a pronociceptive effect of $5-\mathrm{HT}_{7}$ receptor activation in the periphery [17-23]. However, an overall antinociceptive effect has been observed following systemic administration of the selective $5-\mathrm{HT}_{7}$ receptor agonists AS-19, E-57431, and E-55888 to rodents suffering from neuropathic pain $[13,14]$.

On the other hand, $5-\mathrm{HT}_{7}$ receptors have been involved in the control of body temperature based on studies using some $5-\mathrm{HT}_{7}$ receptor agonists (5-CT, 8-OH-DPAT, and LP-211), 5- $-\mathrm{HT}_{7}$ receptor antagonists (SB-258719 and SB269970) and $5-\mathrm{HT}_{7}$ receptor knockout mice. Activation of $5-\mathrm{HT}_{7}$ receptors has been reported to decrease body temperature in a complex manner, in concert with other serotonergic receptors such as the $5-\mathrm{HT}_{1 \mathrm{~A}}$ receptor and/or nonserotonergic receptors [16, 24-28].

In addition to pharmacological studies using $5-\mathrm{HT}_{7}$ receptor agonists and antagonists, the $5-\mathrm{HT}_{7}$ receptor knockout mice may provide a relevant tool to explore the functions of this receptor, and to assess the specificity of ligands supposed to interact selectively with it. Accordingly, the present study examines the effects of the so-called 5$\mathrm{HT}_{7}$ receptor agonists AS-19, E-57431, and E-55888 on formalin-induced pain behavior and thermoregulation in 5$\mathrm{HT}_{7}$ receptor knockout and paired wild-type mice in order to determine the in vivo functional selectivity of these ligands at this specific receptor type.

\section{Materials and Methods}

2.1. Animals. Male, 5- to 8-week-old, 5- $\mathrm{HT}_{7}$ receptor knockout $\left(5-\mathrm{HT}_{7} \mathrm{R}^{-/-}\right)$C57BL/6J mice and their wildtype $5-\mathrm{HT}_{7} \mathrm{R}^{+/+}$siblings used in this study were provided by Deltagen (CA, USA). Embryonic stem cells derived from the 129/OlaHsd mouse substrain were used to generate chimeric mice. F1 mice were generated by breeding with $\mathrm{C} 57 \mathrm{BL} / 6$ females. F2 homozygous mutant mice were produced by intercrossing $\mathrm{F} 1$ heterozygous males and females. Successive mating of heterozygous progeny to the inbred C57BL/6J strain was performed for at least 8 generations before the knockout and wildtype homozygous offsprings were used in the present study. Genotyping was performed by PCR analysis using a protocol described by The Jackson Laboratory (http://jaxmice.jax.org/protocolsdb/f?p=116:2:24205673177 16723::NO:2:P2_MASTER_PROTOCOL_ID,P2_JRS_CODE: 1854,005769). Animals were housed in groups of five, provided with food and water ad libitum and kept in controlled laboratory conditions with ambient temperature maintained at $21 \pm 1^{\circ} \mathrm{C}$ and light in $12 \mathrm{~h}$ cycles (on at 07:00 $\mathrm{h}$ and off at 19:00 h). Experiments were carried out in a sound-attenuated, air-regulated, experimental room. All experimental procedures and animal husbandry were conducted according to ethical principles for the evaluation of pain in conscious animals [29], and to ethical guidelines of the European Communities Council Directive of November 
24, 1986 (86/609/EEC). The experimental work received approval by the Local Ethical Committee.

2.2. Drugs. Formaldehyde ( $37 \mathrm{wt} . \%$ solution) was purchased from Panreac (Spain) and dissolved in physiological saline. Drugs used for treatments were AS-19 (dimethyl-[5-(1,3,5tri-methyl-1H-pyrazol-4-yl)-1,2,3,4-tetrahydro-naphthalen2(S)-yl]-amine) [8, 9], E-55888 (dimethyl-\{2-[3-(1,3,5trimethyl-1H-pyrazol-4-yl)-phenyl]-ethyl $\}$-amine dihydrochloride) [13], and E-57431 (2-(2-(dimethylamino)ethyl)4-(1,3,5-tri-methyl-1H-pyrazol-4-yl)phenol) [14]. AS-19 is a potent selective $5-\mathrm{HT}_{7}$ receptor agonist commercially available from Tocris Bioscience (UK), whereas E-55888 and $\mathrm{E}-57431$ are $5-\mathrm{HT}_{7}$ receptor agonists developed by ESTEVE Laboratories (Barcelona, Spain). All three 5- $\mathrm{HT}_{7}$ receptor agonists were synthesized for the purpose of this study at ESTEVE, dissolved in aqueous solutions containing $0.5 \%$ (hydroxypropyl) methyl cellulose (Sigma-Aldrich, Spain) and administered in a volume of $5 \mathrm{ml} / \mathrm{kg}$ through the subcutaneous (s.c.) route. Doses of drugs (referred to their salt forms) and time of evaluation were selected based on previous studies $[13,14]$ and on pilot experiments in models used in this study. All treatments were performed under blind conditions in independent groups of mice and behavioral evaluation was done $30 \mathrm{~min}$ after drug administration.

\subsection{Nociceptive Behavioral Tests}

2.3.1. Tail Flick Test. Animals were placed in a loose plexiglas restrainer with their tail extruding through a hole to perform the tail flick test as previously described [30]. A photobeam was placed on the tail about $4 \mathrm{~cm}$ from the tip. The latency to tail flick response was recorded automatically to the nearest $0.1 \mathrm{~s}$. The intensity of the radiant heat source was adjusted to yield baseline latencies between 3 and $5 \mathrm{~s}$ in wild-type mice. A cut-off latency of $10 s$ was imposed to avoid damage of tail tissues.

2.3.2. Tail Immersion Test. Animals were placed in a loose plexiglas restrainer with their tail extending through a hole in the water bath of the apparatus (Stuart Bibby Sterilin Ltd, Water Baths SWB1D, UK), as previously described [31]. The lower $2 / 3$ of the tail was immersed in hot water maintained at a constant temperature of $52.0 \pm 0.5^{\circ} \mathrm{C}$. The latency between tail immersion and attempts to remove the tail from the hot water bath was recorded. A cut-off latency of $15 \mathrm{~s}$ was imposed to avoid damage of tail tissues.

2.3.3. Hot Plate Test. Animals were placed individually on the surface of the hot plate apparatus (PanLab, LE 7406, Spain) surrounded by a plexiglas cylinder $(20 \mathrm{~cm}$ in diameter, $25 \mathrm{~cm}$ high). The temperature of the surface was maintained at 55.0 $\pm 0.5^{\circ} \mathrm{C}$, according to the method previously described [32]. The time between placement and the occurrence of forepaw licking (FPL), hindpaw licking (HPL), or jump was recorded as response latency. A cut-off latency of $240 \mathrm{~s}$ was established to avoid damage of paw tissues.
2.3.4. Formalin Test. Formalin $(20 \mu \mathrm{L}$ of a $2.5 \%$ formalin solution; $0.92 \%$ of formaldehyde) was injected into the dorsal surface on the right hind paw, as previously described [33]. The formalin test is a valid and reliable model of nociception with two distinct periods of high licking activity that have different nociceptive mechanisms, an early phase lasting the first $5 \mathrm{~min}$ and a late phase lasting from 15 to $45 \mathrm{~min}$ after the injection of formalin. Mice were placed on a paper surface surrounded by a plexiglas cylinder $(20 \times$ $25 \mathrm{~cm}$ ) and the time spent licking and biting the injected paw was measured using a chronometer. A time course of the licking/biting behaviors was monitored during 45 minutes after formalin injection to evaluate possible differences between genotypes. Drug effects were quantified at $0-5 \mathrm{~min}$ (phase I) and 15-30 min (phase II) after formalin injection, two periods of time in which the formalin-induced licking and biting time was high enough to test antinociceptive effects of drugs.

2.3.5. Rectal Temperature. The body temperature was recorded using a precision thermometer (YSI 4600) equipped with a flexible probe (YSI 402). This probe was lubricated with vaseline and inserted $2 \mathrm{~cm}$ into the rectum. Temperature recordings were made $20 \mathrm{~s}$ following insertion of the probe, as previously described $[27,28]$.

2.4. Data Analysis. Data are presented as mean values \pm S.E.M. Statistical analysis to test significant differences among groups was made using ANOVA followed by Bonferroni's post hoc comparison. Unpaired Student's $t$-test was used to test differences between two groups. The level of significance was set at $P<0.05$. Data analysis and graphing were done using GraphPad Prism software (version 4.0; GraphPad Software Inc., USA).

\section{Results}

3.1. Similar Response to Noxious Thermal Stimuli and Formalin-Induced Nociception in 5-HT 7 Receptor Knockout and Wild-Type Mice. Sensitivity to noxious heat measured as the latency of response to thermal stimulation in the tail flick, tail immersion, and hot plate tests was similar in $5-\mathrm{HT}_{7}$ receptor knockout mice and paired wild-type mice (Figure 1). No significant differences between the two genotypes were found in tail withdrawal latency in the tail flick $\left(t_{49}=1.09, P=0.28\right)$ and tail immersion $\left(t_{49}=1.82\right.$, $P=0.08$ ) tests (Figure 1(a)). Both genotypes showed also the same latency for all measured behaviors in the hot plate test (Figure 1(b)): forepaw licking $\left(t_{49}=1.69, P=0.10\right)$, hindpaw licking $\left(t_{49}=0.73, P=0.47\right)$, and jump $\left(t_{48}=0.81, P=0.42\right)$, suggesting that $5-\mathrm{HT}_{7}$ receptor knockout mice perceive and respond normally to acute thermal nociceptive stimuli. In addition, formalin-induced licking and biting of the paw injected with formalin in $5-\mathrm{HT}_{7}$ receptor knockout mice did not differ from wild-type mice. Repeated measures ANOVA (time $\times$ genotype $)$ showed a significant effect of time $\left(F_{8,162}=\right.$ 24.30, $P<0.001)$, but no effect of genotype $\left(F_{1,162}=1.76\right.$, $P=0.19)$ and no interaction between these two factors 


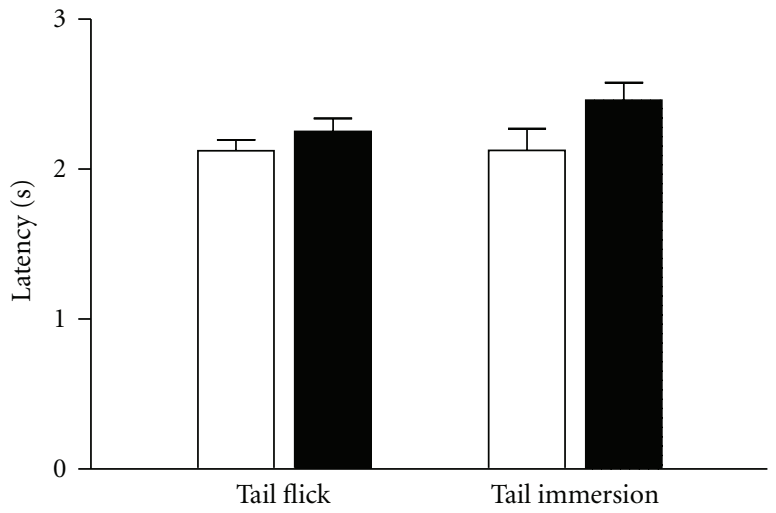

(a) Tail flick and Tail immersion

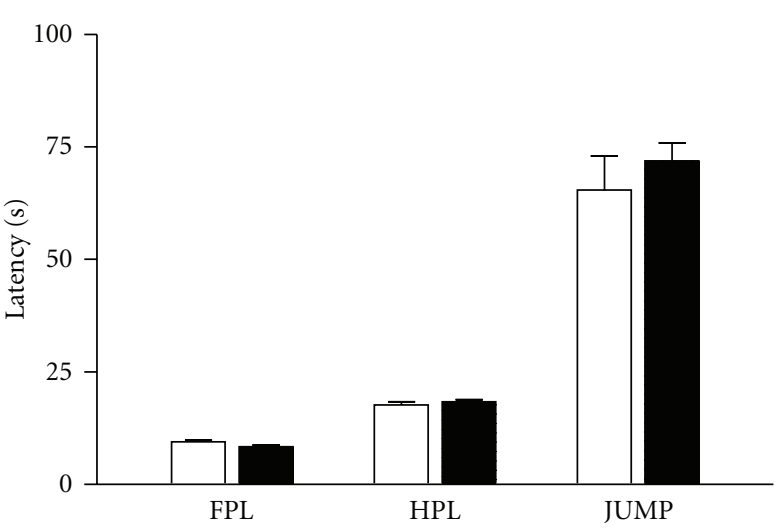

(b) Hot plate $55^{\circ} \mathrm{C}$

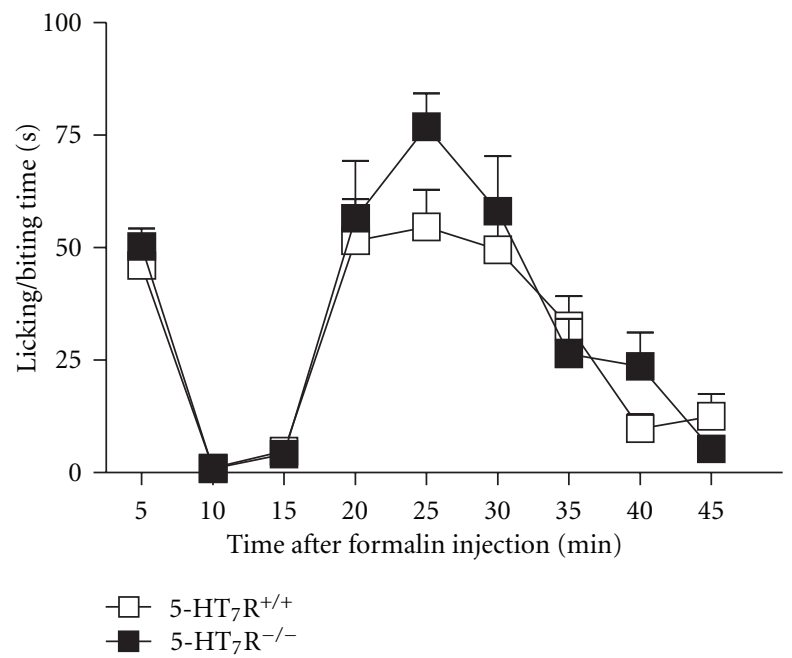

(c) Formalin-induced nociception

Figure 1: Nociceptive behavior of wild-type and 5- $\mathrm{HT}_{7}$ receptor knockout mice in the tail flick and tail immersion tests (a), hot plate $55^{\circ} \mathrm{C}$ test (b), and formalin test (c). Both genotypes showed similar latency for all measured behaviors in the tail flick, tail immersion, and hot plate tests. Formalin-induced licking and biting of the hind paw injected with formalin in $5-\mathrm{HT}_{7}$ receptor knockout mice did not significantly differ from those in wild-type mice either in phase I ( $0-5 \mathrm{~min})$ or in phase II (15-45 min). Only a slight but not significant increase of the licking/biting time was observed $25 \mathrm{~min}$ after formalin injection in 5- $\mathrm{HT}_{7}$ receptor knockout mice compared to wild-type mice. Each bar or symbol represents the mean \pm S.E.M. ( $n=10-12$ per group). Forepaw licking: FPL; hindpaw licking: HPL. No significant differences were observed in thermal nociception (unpaired Student's $t$-test) or formalin-induced nociceptive behaviors (Two-Way ANOVA).

$\left(F_{8,162}=0.90, P=0.52\right)$. A slightly greater licking/biting time was observed $25 \mathrm{~min}$ after formalin injection in the $5-\mathrm{HT}_{7}$ receptor knockout in comparison with wild-type mice, but difference was not significant (Figure 1(c)).

\subsection{5-HT 7 Receptor Agonists Inhibited Selectively Phase II of} Formalin-Induced Nociceptive Behavior in Wild-Type but Not in $5-\mathrm{HT}_{7}$ Receptor Knockout Mice. To examine the in vivo functional specificity of $5-\mathrm{HT}_{7}$ receptor agonists, AS-19, E57431 and E-55888 were subcutaneously administered to wild-type and $5-\mathrm{HT}_{7}$ receptor knockout mice, and treated animals were then subjected to nociceptive tests. Effective doses of AS-19 $(10 \mathrm{mg} / \mathrm{kg})$, E-57431 $(10 \mathrm{mg} / \mathrm{kg})$, and E-55888 $(20 \mathrm{mg} / \mathrm{kg})$ in reversing allodynia/hyperalgesia following capsaicin sensitization and nerve injury $[13,14]$ were used in these experiments. The $5-\mathrm{HT}_{7}$ receptor agonists were administered in the formalin test at doses devoid of motor disturbing effects which could interfere with licking/biting behaviors, as previously described [14].

No significant effects were exerted by $5-\mathrm{HT}_{7}$ receptor agonists on the response to thermal stimuli in the tail flick, tail immersion, and hot plate tests, and the formalin-induced phase I nociceptive behavior was not modified when 5$\mathrm{HT}_{7}$ receptor agonists were administered to wild-type or 5$\mathrm{HT}_{7}$ receptor knockout mice (data not shown). However, all three $5-\mathrm{HT}_{7}$ receptor agonists inhibited phase II of the formalin-induced nociceptive behavior in wild-type mice, as evidenced by a reduction in the duration of licking/biting of the hindpaw injected with formalin (Figure 2). Twoway ANOVA (treatment $\times$ genotype) showed a significant effect of treatment after AS-19 administration $\left(F_{1,38}=\right.$ $10.34, P=0.003)$, without genotype effect $\left(F_{1,38}=0.04\right.$, 


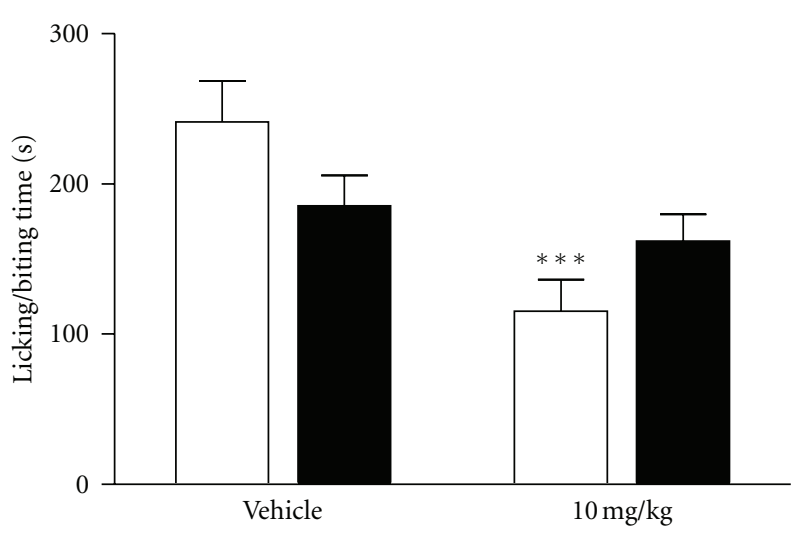

(a) AS-19

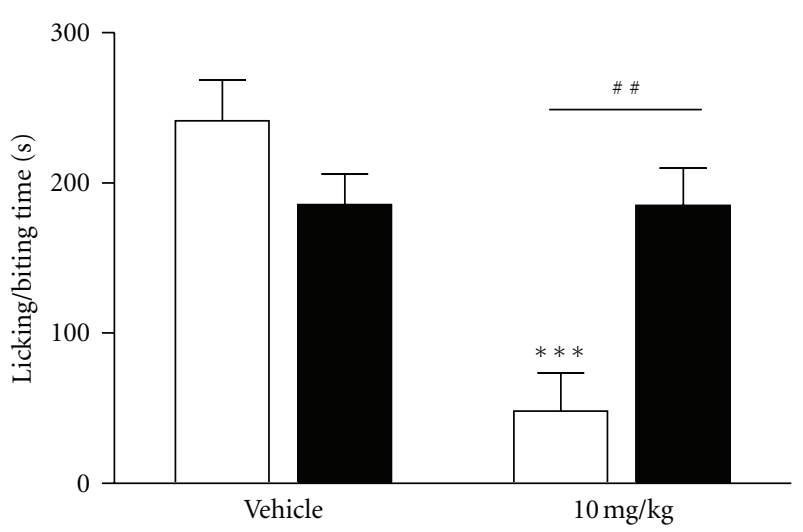

(b) E-57431

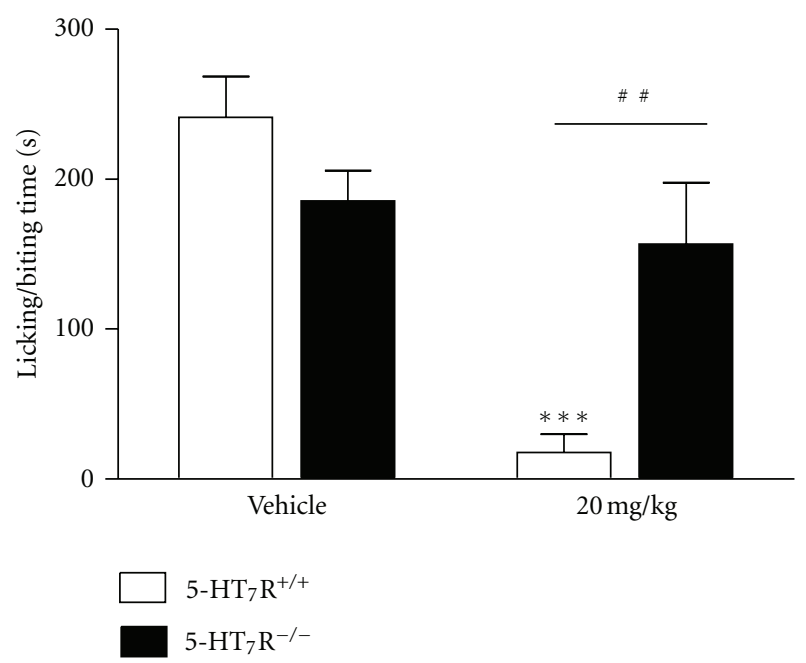

(c) E-55888

FIGURE 2: Effects of 5- $\mathrm{HT}_{7}$ receptor agonists AS-19 (a), E-57431 (b), and E-55888 (c) on formalin-induced nociceptive behaviors during phase II in wild-type and 5- $\mathrm{HT}_{7}$ receptor knockout mice. Subcutaneous administration of AS-19 (10 mg/kg), E-57431 (10 mg/kg), and E$55888(20 \mathrm{mg} / \mathrm{kg})$ significantly reduced the licking/biting time of the hind paw injected with formalin in wild-type but not in 5 - $\mathrm{HT}_{7} \mathrm{receptor}$ knockout mice. Each bar represents the mean \pm S.E.M. $(n=7-12) .{ }^{* * *} P<0.001$ versus vehicle corresponding group; ${ }^{\# \#} P<0.01$ versus corresponding dose in $5-\mathrm{HT}_{7}$ receptor knockout mice (Bonferroni multiple comparison test after ANOVA).

$P=0.84)$ and a significant interaction between these two factors $\left(F_{1,38}=4.86, P=0.03\right)$. The comparison between treatments revealed a significant reduction of licking/biting time after AS-19 administration at $10 \mathrm{mg} / \mathrm{kg}$ in wild-type mice $(P<0.001$; Figure 2). Two-way ANOVA calculated for E-57431 also showed a significant effect of treatment after E-57431 administration $\left(F_{1,39}=15.04, P<0.001\right)$, without genotype effect $\left(F_{1,39}=2.64, P=0.11\right)$ and a significant interaction between these two factors $\left(F_{1,39}=\right.$ 14.91, $P<0.001)$. The comparison between treatments revealed a significant reduction of licking/biting time after E-57431 administration at $10 \mathrm{mg} / \mathrm{kg}$ in wild-type mice $(P<$ 0.001; Figure 2). In addition, a significant difference was found between genotypes when E-57431 was administered at $10 \mathrm{mg} / \mathrm{kg}(P<0.01$; Figure 2$)$. In the same way, twoway ANOVA calculated for E-55888 also showed a significant effect of treatment after E-55888 administration $\left(F_{1,35}=22.3\right.$, $P<0.001)$, without genotype effect $\left(F_{1,35}=2.42, P=\right.$ 0.13 ) and a significant interaction between these two factors
$\left(F_{1,35}=13.32, P<0.001\right)$. The comparison between treatments revealed a significant reduction of licking/biting time after E-55888 administration at $20 \mathrm{mg} / \mathrm{kg}$ in wildtype mice $(P<0.001$; Figure 2$)$. In addition, a significant difference was found between genotypes when E-55888 was administered at $20 \mathrm{mg} / \mathrm{kg}(P<0.01$; Figure 2$)$. Interestingly, none of the three $5-\mathrm{HT}_{7}$ receptor agonists exerted significant effects on formalin phase II nociceptive behavior in $5-\mathrm{HT}_{7}$ receptor knockout mice (Figure 2).

3.3. Selective Doses of 5-HT7 Receptor Agonists Produced No Effect on Body Temperature in 5-HT $T_{7}$ Receptor Knockout and Wild-Type Mice. The in vivo specificity of the $5-\mathrm{HT}_{7}$ receptor agonists (AS-19, E-57431, and E-55888) was further examined using $5-\mathrm{HT}_{7}$ receptor knockout and paired wildtype mice in the paradigm based on $5-\mathrm{HT}_{7}$ receptormediated hypothermia [27]. Basal body temperature did not significantly differ in $5-\mathrm{HT}_{7}$ receptor knockout and 


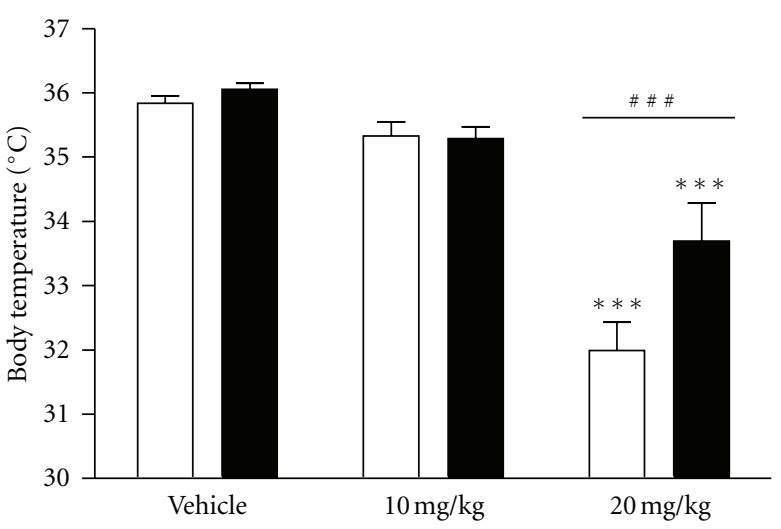

(a) AS-19

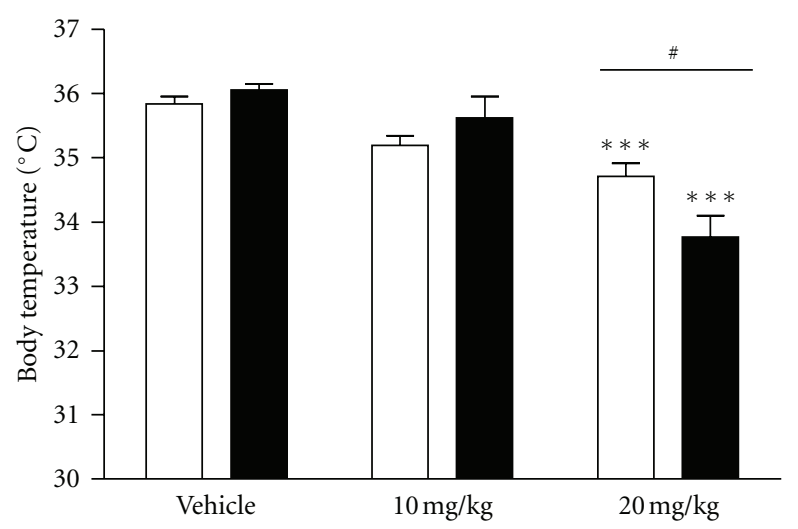

(b) E-5743

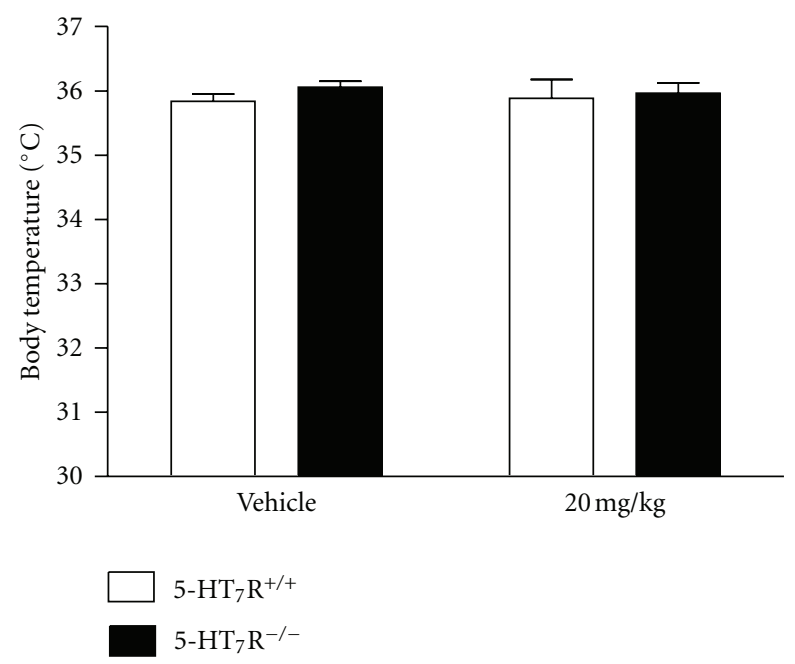

(c) E-55888

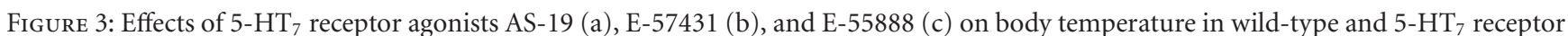
knockout mice. Subcutaneous administration of AS-19 and E-57431 at $20 \mathrm{mg} / \mathrm{kg}$ significantly reduced body temperature in both wildtype and $5-\mathrm{HT}_{7}$ receptor knockout mice and showed significant differences between both genotypes. However, E-55888 at $20 \mathrm{mg} / \mathrm{kg}$ did not reduce the body temperature neither in wild-type nor in $5-\mathrm{HT}_{7}$ knockout mice. Each bar represents the mean \pm S.E.M. $(n=8-12)$. ${ }^{* * *} P<0.001$ versus vehicle corresponding group; ${ }^{\#} P<0.05$; ${ }^{\# \# ~} P<0.001$ versus corresponding dose in 5 - $\mathrm{HT}_{7}$ receptor knockout mice (Bonferroni multiple comparison test post-ANOVA).

paired wild-type mice $\left(36.1 \pm 0.1^{\circ} \mathrm{C}\right.$ and $35.8 \pm 0.1^{\circ} \mathrm{C}$, resp.; Figure 3).

Two-way ANOVA (treatment $\times$ genotype) showed a significant effect of treatment after AS-19 administration $\left(F_{2,49}=62.17, P<0.001\right)$, with genotype effect $\left(F_{1,49}=6.88\right.$, $P=0.01)$ and a significant interaction between these two factors $\left(F_{2,49}=4.77, P=0.01\right)$. The comparison between treatments revealed a significant reduction of body temperature after AS-19 administration at $20 \mathrm{mg} / \mathrm{kg}$ in wild-type and $5-\mathrm{HT}_{7}$ receptor knockout mice $(P<0.001$; Figure 3$)$. In addition, a significant difference was found between genotypes when AS-19 was administered at $20 \mathrm{mg} / \mathrm{kg}(P<$ 0.001; Figure 3). Two-way ANOVA calculated for E-57431 also showed a significant effect of treatment after E-57431 administration $\left(F_{2,49}=35.85, P<0.001\right)$, without genotype effect $\left(F_{1,49}=0.31, P=0.58\right)$ and a significant interaction between these two factors $\left(F_{2,49}=5.82, P=0.005\right)$. The comparison between treatments revealed a significant reduction of body temperature after E-57431 administration at $20 \mathrm{mg} / \mathrm{kg}$ in wild-type and $5-\mathrm{HT}_{7}$ receptor knockout mice $(P<0.001$; Figure 3$)$. In addition, a significant difference was found between genotypes when E-57431 was administered at $20 \mathrm{mg} / \mathrm{kg}(P<0.05$; Figure 3$)$. However, two-way ANOVA calculated for E-55888 did not show significant differences on treatment after E-55888 administration $\left(F_{1,35}=0.02, P=\right.$ $0.89)$, neither genotype effect $\left(F_{1,35}=0.91, P=0.35\right)$ nor interaction between these two factors $\left(F_{1,35}=0.21, P=0.65\right)$. The comparison between treatments and genotypes did not reveal significant reduction of body temperature after E55888 administration at $20 \mathrm{mg} / \mathrm{kg}(P>0.05$; Figure 3$)$.

Subcutaneous administration of doses of AS-19 $(10 \mathrm{mg} / \mathrm{kg}), \mathrm{E}-57431(10 \mathrm{mg} / \mathrm{kg})$, and E-55888 $(20 \mathrm{mg} / \mathrm{kg})$ which exerted analgesic effects in phase II formalin-induced pain, did not significantly change body temperature neither in $5-\mathrm{HT}_{7}$ receptor wild-type nor in knockout mice (Figure 3). However, administration of a higher dose 
$\left(20 \mathrm{mg} / \mathrm{kg}\right.$, s.c.) of the $5-\mathrm{HT}_{7}$ receptor agonists AS-19 and E-57431 significantly reduced body temperature in both genotypes (Figure 3), suggesting that at such a high dose the selectivity window of AS-19 and E-57431 was overstepped. AS-19 at the $20 \mathrm{mg} / \mathrm{kg}$ dose produced a higher body temperature reduction in wild-type than in $5-\mathrm{HT}_{7}$ receptor knockout mice (3.8 versus $2.4^{\circ} \mathrm{C}$, resp.). In contrast, E-57431 at the same high dose $(20 \mathrm{mg} / \mathrm{kg})$ produced a lower body temperature reduction in wild-type than in $5-\mathrm{HT}_{7}$ receptor knockout mice (1.1 versus $2.3^{\circ} \mathrm{C}$, resp.) (Figure 3 ).

\section{Discussion}

In this study, the in vivo target-specific effects of the $5-\mathrm{HT}_{7}$ receptor agonists AS-19, E-57431, and E-55888 on nociception (i.e., formalin-induced nociception) and thermoregulation were examined using $5-\mathrm{HT}_{7}$ receptor knockout mice. These $5-\mathrm{HT}_{7}$ receptor agonists exerted antinociceptive effects in phase II of the formalin test in wild-type but not in 5$\mathrm{HT}_{7}$ receptor knockout mice, suggesting that their analgesic effect is actually $5-\mathrm{HT}_{7}$ receptor mediated. Analgesic doses of $5-\mathrm{HT}_{7}$ receptor agonists did not change body temperature neither in $5-\mathrm{HT}_{7}$ receptor knockout nor in wild-type mice. However, a reduction in body temperature was observed in both genotypes when the dose of the agonists were increased up to levels exceeding their selectivity window.

The $5-\mathrm{HT}_{7}$ receptor knockout mice offer a complementary approach to classical pharmacology and might provide insights into the functional implications of 5$\mathrm{HT}_{7}$ receptors. To date, data obtained with these mutants suggest the involvement of $5-\mathrm{HT}_{7}$ receptors in depression, schizophrenia, sleep, learning, locomotion, and hypothermia $[25,28,34-37]$.

In this work, we demonstrated that sensitivity to noxious heat measured as the latency time of response to thermal stimulation in the tail flick, tail immersion, and hot plate tests did not differ in $5-\mathrm{HT}_{7}$ receptor knockout compared to wild-type mice, as previously described [38]. In addition, the formalin-induced nociceptive behavior of $5-\mathrm{HT}_{7}$ receptor knockout mice was not different from wild-type mice as no significant differences in licking/biting time were found between both genotypes, for either phase I or phase II of the formalin test. These results suggest that basic mechanisms for transduction, transmission, and perception of, as well as response to, nociceptive stimuli are intact in mice lacking 5$\mathrm{HT}_{7}$ receptors. As previously reported, the loss of function of the missing $5-\mathrm{HT}_{7}$ receptor could induce possible adaptive changes which could compensate for some alterations, thereby resulting in wild-type-like responses [38-40].

Thermal nociception and early phase response in the formalin test are caused predominantly by direct activation of peripheral C-fibers, whereas the late response (phase II) in the formalin test involves functional changes in the dorsal horn of the spinal cord (i.e., central sensitization) [41-43]. In this study, subcutaneous administration of $5-\mathrm{HT}_{7}$ receptor agonists was devoid of activity in acute nociceptive tests (i.e., thermal- and formalin-induced phase I nociception), but exerted clear-cut antinociceptive effects in phase II of the formalin test in wild-type mice. These results are in line with previous studies showing that $5-\mathrm{HT}_{7}$ receptor agonists and antagonists were ineffective in acute thermal nociceptive pain [44-47]. The lack of antinociceptive effects in thermal and phase I formalin-induced nociception, observed when $5-\mathrm{HT}_{7}$ receptor agonists were administered, suggests no direct modulation by the $5-\mathrm{HT}_{7}$ receptor subtype of acute nociceptive signals coming from small caliber unmyelinated nociceptive afferents. However, activation of spinal $5-\mathrm{HT}_{7}$ receptors has been shown to play a role in the antinociceptive effects of opioids [44-47].

Our results on phase II formalin-induced behavior are in line with previous reports describing antinociceptive effects of selective $5-\mathrm{HT}_{7}$ receptor agonists by systemic or spinal administration in neurogenic and neuropathic pain conditions involving central sensitization $[13,14,17]$. However, a clear-cut pronociceptive (proallodynic) effect was found when a $5-\mathrm{HT}_{7}$ receptor agonist was administered intraplantarly into the ipsilateral hind paw injected with a low subactive dose of capsaicin [17]. In contrast, data in the literature using the formalin test suggest a pronociceptive role of both peripheral and spinal $5-\mathrm{HT}_{7}$ receptors. Indeed, intraplantar or spinal administration of 5-carboxamidotryptamine, a nonselective $5-\mathrm{HT}_{7}$ receptor agonist, increased phase II formalin-induced nociceptive behavior, and these effects were significantly reversed by the selective $5-\mathrm{HT}_{7}$ receptor antagonist SB-269970 [23]. Differences could be due to species (mice versus rats), primary administration route (systemic versus spinal and local peripheral), selectivity of the $5-\mathrm{HT}_{7}$ agonists used and animal models.

To further assess the in vivo specificity of the $5-\mathrm{HT}_{7}$ receptor agonists used in this study, we examined in $5-\mathrm{HT}_{7}$ receptor knockout mice, the effects of the $5-\mathrm{HT}_{7}$ receptor agonists AS-19, E-57431, and E-55888 on both formalininduced nociception and body temperature. Under our experimental conditions, $5-\mathrm{HT}_{7}$ receptor agonists, at doses effective to reduce phase II formalin-induced nociceptive behavior, affected body temperature neither in wild-type mice nor in 5- $\mathrm{HT}_{7}$ knockout mutants. However, AS-19 and E-57431 at the high dose of $20 \mathrm{mg} / \mathrm{kg}$ significantly reduced body temperature not only in wild-type but also in $5-\mathrm{HT}_{7}$ receptor knockout mice, indicating a non-5$\mathrm{HT}_{7}$ receptor-mediated effect possibly due to interactions of these compounds with other 5-HT receptors when their selectivity window is surpassed. In line with this interpretation, we found that E-55888, the most selective 5$\mathrm{HT}_{7}$ receptor agonist based on in vitro radioligand binding assays (Table 1), even at the dose of $20 \mathrm{mg} / \mathrm{kg}$, did not exert any effect on body temperature in both genotypes. Taken together, the finding that the less selective agonists (AS19 and E-57431) at high doses reduced body temperature in both wild-type and knockout mice, whereas the most selective one (E-55888) did not, suggests that activation of $5-\mathrm{HT}_{7}$ receptors alone is not enough to affect body temperature. Our results do not rule out the possibility that $5-\mathrm{HT}_{7}$ receptors might contribute to the regulation of body temperature by acting in concert with other serotonergic and/or nonserotonergic receptors. Indeed, we found a higher 
hypothermic effect induced by AS-19 $(20 \mathrm{mg} / \mathrm{kg})$ in wildtype compared to $5-\mathrm{HT}_{7}$ receptor knockout mice, suggesting that $5-\mathrm{HT}_{7}$ receptors might promote the decrease in body temperature when other mechanisms are also recruited. The in vitro binding profile of these ligands (see Table 1) suggests that $5-\mathrm{HT}_{1 \mathrm{D}}$ and/or $5-\mathrm{HT}_{1 \mathrm{~A}}$ receptors could be involved in the observed hypothermic effects of AS-19 and E-57431, also because activation of these receptor types has been reported to induce hypothermia $[16,28,48]$. Overall, as previously reported, $5-\mathrm{HT}_{7}$ receptors appear to be involved in a complex manner in thermoregulation, probably through mechanisms implicating direct/indirect interactions between $5-\mathrm{HT}_{7}$ receptors and other molecular targets.

\section{Conclusions}

Data obtained in this study strengthen the notion that $5-\mathrm{HT}_{7}$ receptors play a role in nociceptive control in pain conditions involving central sensitization and add further support to their fine-tuning effects in body temperature homeostasis through possible actions in concert with other molecular targets. In addition, this study provides evidence that formalininduced nociceptive behaviors and body temperature in 5$\mathrm{HT}_{7}$ receptor knockout mice are useful models and relatively simple approaches to assess in vivo specificity of $5-\mathrm{HT}_{7}$ receptor agonists.

\section{Authors' Contribution}

A. Brenchat and M. Rocasalbas contributed equally to this paper.

\section{Conflict of Interests}

There was no conflict of interests with respect to the work reported in the paper.

\section{Acknowledgment}

The authors thank Mrs. Mercè Olivet for her administrative assistance.

\section{References}

[1] P. B. Hedlund, "The 5- $\mathrm{HT}_{7}$ receptor and disorders of the nervous system: an overview," Psychopharmacology, vol. 206, no. 3, pp. 345-354, 2009.

[2] M. Leopoldo, E. Lacivita, F. Berardi, R. Perrone, and P. B. Hedlund, "Serotonin $5-\mathrm{HT}_{7}$ receptor agents: structure-activity relationships and potential therapeutic applications in central nervous system disorders," Pharmacology and Therapeutics, vol. 129, no. 2, pp. 120-148, 2011.

[3] D. J. Cushing, J. M. Zgombick, D. L. Nelson, and M. L. Cohen, "LY215840, a high-affinity 5- $\mathrm{HT}_{7}$ receptor ligand, blocks serotonin-induced relaxation in canine coronary artery," Journal of Pharmacology and Experimental Therapeutics, vol. 277, no. 3, pp. 1560-1566, 1996.

[4] I. T. Forbes, S. Dabbs, D. M. Duckworth et al., “(R)-3,N-Dimethyl-N-[1-methyl-3-(4-methyl-piperidin-1-yl)propyl] benzenesulfonamide: the first selective $5-\mathrm{HT}_{7}$ receptor antagonist," Journal of Medicinal Chemistry, vol. 41, no. 5, pp. 655-657, 1998.

[5] C. Kikuchi, H. Nagaso, T. Hiranuma, and M. Koyama, "Tetrahydrobenzindoles: selective antagonists of the $5-\mathrm{HT}_{7}$ receptor," Journal of Medicinal Chemistry, vol. 42, no. 4, pp. 533-535, 1999.

[6] P. J. Lovell, S. M. Bromidge, S. Dabbs et al., "A novel, potent, and selective 5- $\mathrm{HT}_{7}$ antagonist: (R)-3-(2-(2-(4methylpiperidin-1-yl)- ethyl)pyrrolidine-1-sulfonyl)phenol (SB-269970)," Journal of Medicinal Chemistry, vol. 43, no. 3, pp. 342-345, 2000.

[7] I. T. Forbes, S. Douglas, A. D. Gribble et al., "SB-656104A: a novel $5-\mathrm{HT}_{7}$ receptor antagonist with improved in vivo properties," Bioorganic and Medicinal Chemistry Letters, vol. 12, no. 22, pp. 3341-3344, 2002.

[8] A. M. Johansson, M. Brisander, A. Sanin, S. Rosqvist, N. Mohell, A. Malmberg et al., "5-Aryl substituted (S)-2(dimethylamino)-tetralins: novel serotonin $5-\mathrm{HT}_{7}$ receptor ligands," in Proceedings of the 226th American Chemical Society National Meeting, New York, NY, USA, 2003.

[9] A. Sanin, M. Brisander, S. Rosqvist, N. Mohell, A. Malberg, A. Johansson et al., "5-Aryl substituted (S)-2-(dimethylamino)tetralins novel serotonin $5 \mathrm{HT}_{7}$ receptor ligands," in Proceedings of the 14th Camerino-Noord Symposium, Ongoing Progress in the Receptor Chemistry, Camerino, Italy, 2003.

[10] C. G. Thomson, M. S. Beer, N. R. Curtis, H. J. Diggle, E. Handford, and J. J. Kulagowski, "Thiazoles and thiopyridines: novel series of high affinity h5 $\mathrm{HT}_{7}$ ligands," Bioorganic and Medicinal Chemistry Letters, vol. 14, no. 3, pp. 677-680, 2004.

[11] M. Leopoldo, F. Berardi, N. A. Colabufo et al., "Structure-affinity relationship study on $\mathrm{N}-(1,2,3,4$-tetrahydronaphthalen-1-yl)-4-aryl-1-piperazinealkylamides, a new class of 5-hydroxytryptamine 7 receptor agents," Journal of Medicinal Chemistry, vol. 47, no. 26, pp. 6616-6624, 2004.

[12] M. Leopoldo, E. Lacivita, P. De Giorgio et al., "Structural modifications of $\mathrm{N}$-(1,2,3,4-tetrahydronaphthalen-1-yl)-4-aryl-1piperazinehexanamides: Influence on lipophilicity and $5-\mathrm{HT}_{7}$ receptor activity. Part III," Journal of Medicinal Chemistry, vol. 51, no. 18, pp. 5813-5822, 2008.

[13] A. Brenchat, L. Romero, M. García et al., "5-HT 7 receptor activation inhibits mechanical hypersensitivity secondary to capsaicin sensitization in mice," Pain, vol. 141, no. 3, pp. 239247, 2009.

[14] A. Brenchat, X. Nadal, L. Romero et al., "Pharmacological activation of $5-\mathrm{HT}_{7}$ receptors reduces nerve injury-induced mechanical and thermal hypersensitivity," Pain, vol. 149, no. 3, pp. 483-494, 2010.

[15] M. Leopoldo, E. Lacivita, M. Contino, N. A. Colabufo, F. Berardi, and R. Perrone, "Structure-activity relationship study on $\mathrm{N}$-(1,2,3,4-tetrahydronaphthalen-1- yl)-4-aryl-1piperazinehexanamides, a class of $5-\mathrm{HT}_{7}$ receptor agents," Journal of Medicinal Chemistry, vol. 50, no. 17, pp. 4214-4221, 2007.

[16] P. B. Hedlund, M. Leopoldo, S. Caccia et al., "LP-211 is a brain penetrant selective agonist for the serotonin $5-\mathrm{HT}_{7}$ receptor," Neuroscience Letters, vol. 481, no. 1, pp. 12-16, 2010.

[17] A. Brenchat, D. Zamanillo, M. Hamon, L. Romero, J. M. Vela et al., "Role of peripheral versus spinal $5-\mathrm{HT}_{7}$ receptors in the modulation of pain under sensitizing conditions," European Journal of Pain, vol. 16, no. 1, pp. 72-81, 2012.

[18] M. I. Diaz-Reval, R. Ventura-Martinez, M. Deciga-Campos, J. A. Terron, F. Cabre, F. J. Lopez-Munoz et al., "Evidence for a 
central mechanism of action of S-(+)-ketoprofen," European Journal of Pharmacology, vol. 483, no. 2-3, pp. 241-248, 2004.

[19] S. Doly, J. Fischer, M. J. Brisorgueil, D. Vergé, and M. Conrath, "Pre- and postsynaptic localization of the $5-\mathrm{HT}_{7}$ receptor in rat dorsal spinal cord: immunocytochemical evidence," Journal of Comparative Neurology, vol. 490, no. 3, pp. 256-269, 2005.

[20] S. E. Harte, R. G. Kender, and G. S. Borszcz, "Activation of 5$\mathrm{HT}_{1 \mathrm{~A}}$ and $5-\mathrm{HT}_{7}$ receptors in the parafascicular nucleus suppresses the affective reaction of rats to noxious stimulation," Pain, vol. 113, no. 3, pp. 405-415, 2005.

[21] T. Meuser, C. Pietruck, A. Gabriel, G. X. Xie, K. J. Lim, and P. Pierce Palmer, " $5-\mathrm{HT}_{7}$ receptors are involved in mediating 5HT-induced activation of rat primary afferent neurons," Life Sciences, vol. 71, no. 19, pp. 2279-2289, 2002.

[22] J. F. Neumaier, T. J. Sexton, J. Yracheta, A. M. Diaz, and M. Brownfield, "Localization of $5-\mathrm{HT}_{7}$ receptors in rat brain by immunocytochemistry, in situ hybridization, and agonist stimulated cFos expression," Journal of Chemical Neuroanatomy, vol. 21, no. 1, pp. 63-73, 2001.

[23] H. I. Rocha-González, A. Meneses, S. M. Carlton, and V. Granados-Soto, "Pronociceptive role of peripheral and spinal $5-\mathrm{HT}_{7}$ receptors in the formalin test," Pain, vol. 117, no. 1-2, pp. 182-192, 2005.

[24] M. R. Guscott, E. Egan, G. P. Cook et al., "The hypothermic effect of 5-CT in mice is mediated through the $5-\mathrm{HT}_{7}$ receptor," Neuropharmacology, vol. 44, no. 8, pp. 1031-1037, 2003.

[25] M. Guscott, L. J. Bristow, K. Hadingham et al., "Genetic knockout and pharmacological blockade studies of the 5$\mathrm{HT}_{7}$ receptor suggest therapeutic potential in depression," Neuropharmacology, vol. 48, no. 4, pp. 492-502, 2005.

[26] J. J. Hagan, G. W. Price, P. Jeffrey et al., "Characterization of SB-269970-A, a selective 5- $\mathrm{HT}_{7}$ receptor antagonist," British Journal of Pharmacology, vol. 130, no. 3, pp. 539-548, 2000.

[27] P. B. Hedlund, P. E. Danielson, E. A. Thomas, K. Slanina, M. J. Carson, and J. G. Sutcliffe, "No hypothermic response to serotonin in 5- $\mathrm{HT}_{7}$ receptor knockout mice," Proceedings of the National Academy of Sciences of the United States of America, vol. 100, no. 3, pp. 1375-1380, 2003.

[28] P. B. Hedlund, L. Kelly, C. Mazur, T. Lovenberg, J. G. Sutcliffe, and P. Bonaventure, "8-OH-DPAT acts on both $5-\mathrm{HT}_{1 \mathrm{~A}}$ and $5-\mathrm{HT}_{7}$ receptors to induce hypothermia in rodents," European Journal of Pharmacology, vol. 487, no. 1-3, pp. 125-132, 2004.

[29] M. Zimmermann, "Ethical guidelines for investigations of experimental pain in conscious animals," Pain, vol. 16, no. 2, pp. 109-110, 1983.

[30] F. E. D’Amour, D. L. Smith et al., "A method for determining loss of pain sensation," Journal of Pharmacology and Experimental Therapeutics, vol. 72, no. 1, pp. 74-79, 1941.

[31] K. Ramabadran, M. Bansinath, H. Turndorf, and M. M. Puig, "Tail immersion test for the evaluation of a nociceptive reaction in mice. Methodological considerations," Journal of Pharmacological Methods, vol. 21, no. 1, pp. 21-31, 1989.

[32] G. Woolfe, A. D. MacDonald et al., "The evaluation of the analgesic action of pethidine hydrochloride (Demerol)," Journal of Pharmacology and Experimental Therapeutics, vol. 80, no. 3, pp. 300-307, 1944.

[33] S. Hunskaar and K. Hole, "The formalin test in mice: dissociation between inflammatory and non-inflammatory pain," Pain, vol. 30, no. 1, pp. 103-114, 1987.

[34] R. Galici, J. D. Boggs, K. L. Miller, P. Bonaventure, and J. R. Atack, "Effects of SB-269970, a 5- $\mathrm{HT}_{7}$ receptor antagonist, in mouse models predictive of antipsychotic-like activity," Behavioural Pharmacology, vol. 19, no. 2, pp. 153-159, 2008.

[35] P. B. Hedlund, S. Huitron-Resendiz, S. J. Henriksen, and J. G. Sutcliffe, " $5-\mathrm{HT}_{7}$ receptor inhibition and inactivation induce antidepressantlike behavior and sleep pattern," Biological Psychiatry, vol. 58, no. 10, pp. 831-837, 2005.

[36] J. Liu, T. Akay, P. B. Hedlund, K. G. Pearson, and L. M. Jordan, "Spinal $5-\mathrm{HT}_{7}$ receptors are critical for alternating activity during locomotion: In vitro neonatal and in vivo adult studies using $5-\mathrm{HT}_{7}$ receptor knockout mice," Journal of Neurophysiology, vol. 102, no. 1, pp. 337-348, 2009.

[37] J. Shelton, P. Bonaventure, X. Li, S. Yun, T. Lovenberg, and C. Dugovic, " $5-\mathrm{HT}_{7}$ receptor deletion enhances REM sleep suppression induced by selective serotonin reuptake inhibitors, but not by direct stimulation of $5-\mathrm{HT}_{1 \mathrm{~A}}$ receptor," Neuropharmacology, vol. 56, pp. 448-454, 2009.

[38] A. J. Roberts, T. Krucker, C. L. Levy, K. A. Slanina, J. G. Sutcliffe, and P. B. Hedlund, "Mice lacking $5-\mathrm{HT}_{7}$ receptors show specific impairments in contextual learning," European Journal of Neuroscience, vol. 19, no. 7, pp. 1913-1922, 2004.

[39] G. Sarkisyan and P. B. Hedlund, "The $5-\mathrm{HT}_{7}$ receptor is involved in allocentric spatial memory information processing," Behavioural Brain Research, vol. 202, no. 1, pp. 26-31, 2009.

[40] S. Semenova, M. A. Geyer, J. G. Sutcliffe, A. Markou, and P. B. Hedlund, "Inactivation of the $5-\mathrm{HT}_{7}$ receptor partially blocks phencyclidine-induced disruption of prepulse inhibition," Biological Psychiatry, vol. 63, no. 1, pp. 98-105, 2008.

[41] T. J. Coderre and R. Melzack, "The contribution of excitatory amino acids to central sensitization and persistent nociception after formalin-induced tissue injury," Journal of Neuroscience, vol. 12, no. 9, pp. 3665-3670, 1992.

[42] A. Tjølsen, O. G. Berge, S. Hunskaar, J. H. Rosland, and K. Hole, "The formalin test: an evaluation of the method," Pain, vol. 51, no. 1, pp. 5-17, 1992.

[43] K. Vissers, V. Hoffmann, F. Geenen, R. Biermans, and T. Meert, "Is the second phase of the formalin test useful to predict activity in chronic constriction injury models? A pharmacological comparison in different species," Pain Practice, vol. 3, pp. 298-309, 2003.

[44] A. Brenchat, M. Ejarque, D. Zamanillo, J. M. Vela, L. Romero et al., "Potentiation of morphine analgesia by adjuvant activation of $5-\mathrm{HT}_{7}$ receptors," Journal of Pharmacological Sciences, vol. 116, no. 4, pp. 388-391, 2011.

[45] A. Dogrul, M. H. Ossipov, and F. Porreca, "Differential mediation of descending pain facilitation and inhibition by spinal $5 \mathrm{HT}_{3}$ and $5 \mathrm{HT}_{7}$ receptors," Brain Research, vol. 1280, pp. 52-59, 2009.

[46] A. Dogrul and M. Seyrek, "Systemic morphine produce antinociception mediated by spinal $5-\mathrm{HT}_{7}$, but not $5-\mathrm{HT}_{1 \mathrm{~A}}$ and $5-\mathrm{HT}_{2}$ receptors in the spinal cord," British Journal of Pharmacology, vol. 149, no. 5, pp. 498-505, 2006.

[47] O. Yanarates, A. Dogrul, V. Yildirim et al., "Spinal 5- $\mathrm{HT}_{7}$ receptors play an important role in the antinociceptive and antihyperalgesic effects of tramadol and its metabolite, odesmethyltramadol, via activation of descending serotonergic pathways," Anesthesiology, vol. 112, no. 3, pp. 696-710, 2010.

[48] H. O. Kalkman and V. Neumann, "Evidence for a 5-HT receptor-mediated hypothermic effect of the $\alpha 1$-adrenoceptor agonist, SDZ NVI-085, in guinea-pigs," European Journal of Pharmacology, vol. 285, no. 3, pp. 313-315, 1995. 

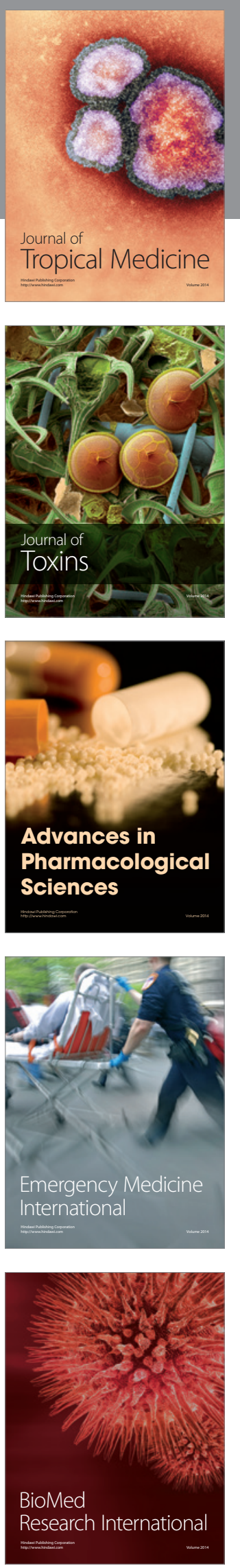
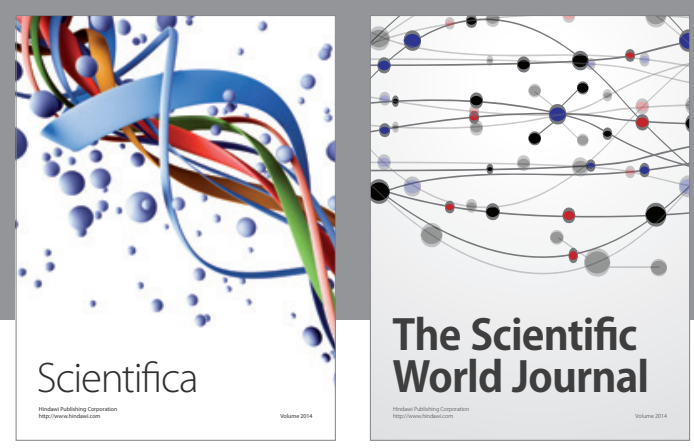

The Scientific World Journal
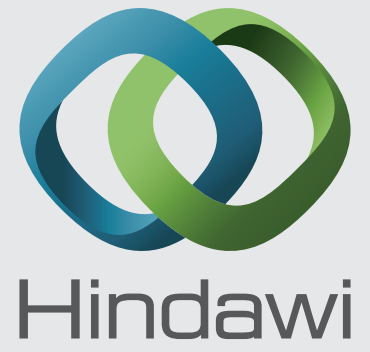

Submit your manuscripts at

http://www.hindawi.com
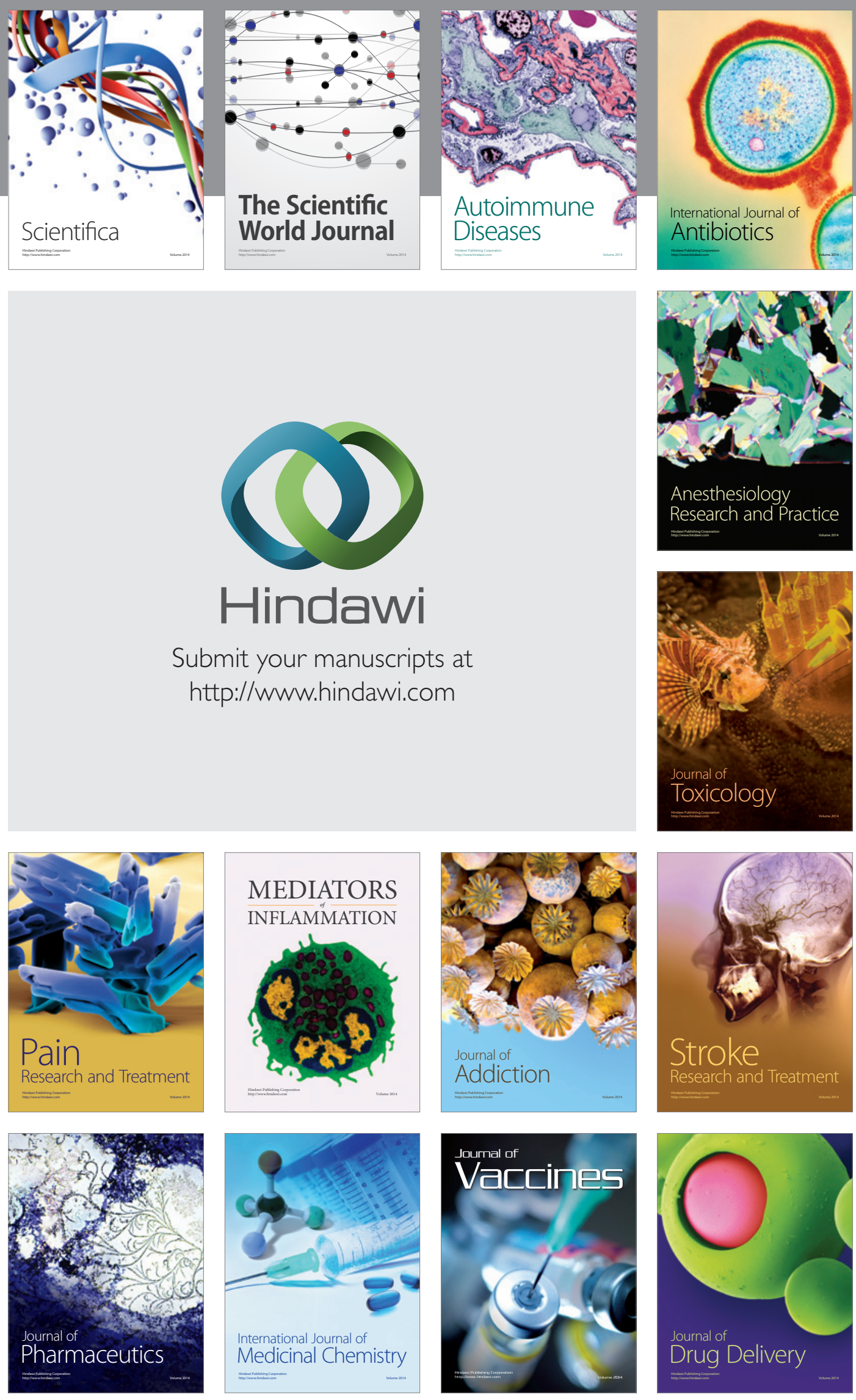